\title{
Students' Participation in Governance and Organizational Effectiveness in Universities in Nigeria
}

\author{
Dr Adegun Olajire Adeola
}

Institute of Education, Ekiti State University, Ado-Ekiti Nigeria

jireadegun@yahoo.com

\section{Dr. Arogundade Babatope Bukola}

\author{
Department of Educational Foundations and Management Ekiti State University, Ado-Ekiti
} dr-arogundade@yahoo.com

\author{
Doi:10.5901/mjss.2014.v5n9p400
}

\begin{abstract}
This paper examined the level of students' participation in governance of Universities. It also investigated the level of organizational effectiveness in the universities in Nigeria. The population of the study consists of all students in Federal and State Universities in Ekiti and Ondo State of Nigeria. The sample for the study was 510 subjects consisting of 400 students and 110 University administrators. The respondents were selected using stratified random sampling technique. The instruments tagged Students' Participation in University Governance Questionnaire (SPUGQ) and Organizational Effectiveness Questionnaire [OEQ] was used to elicit relevant information from the respondents. Frequency count, percentage and t-test statistics were used to analyze the data collected. The findings revealed that students' participation in University governance was low while organization effectiveness was moderate. The result showed that there was significant difference in students' participation in governance in Federal and State Universities. Students in Federal Universities participated more in the governance than students in State Universities. Finding also revealed that there was significant difference in Organizational effectiveness of Federal and State Universities. The Organization effectiveness of Federal University is higher than the State Universities. It was recommended that stakeholders in University education should ensure that students are more involved in the governance of their institutions. Also introduction of seminars and workshops on leadership training would enhance organizational effectiveness in the Universities.
\end{abstract}

\section{Introduction}

In today's rapidly transforming and globalizing information society, there are growing demands from all nations of the world for education to equip citizens with abilities to meet the various emerging challenges. Individuals need to have access to a form of continuous learning that will enable them to understand themselves and their environment. There is a need for learning which introduces individuals to many forms of knowledge and improve their contributions to their communities. In this connection, universities have been known all over the world and throughout the ages as veritable for establishing very good cultural and intellectual standards for the guidance and development of the societies in which they are situated.

The concepts of effective organization and good corporate governance have much in common and have received considerable attention in recent years (Tajomarwo, 2009). According to Tajomariwo, the effective organization is one that is able to admire goals or results, and is able to meet its obligation to all stakeholders, now and in the distant future.

He further explained that an organization is an institution with some aims and objectives to achieve. Organization stands for a structure, framework, system, organized body, assortment, organism and a set or collection. It is concerned with the process of regulations, form, material equipment, human equipment and other facilities of work. This organization deals with making systematic arrangements so that the purposes of the entire programme, are achieved. The school has to function as an effective and efficient organization. Good organization ensures unity of action, efficiency, economy, optimum utilization of resources well-being, all round satisfaction and good results. Without proper organization there would be confusion, chaos and haphazard activity resulting into wastage of time, effort and resources.

However, organizational effectiveness in the university system could be measured in terms of realization of the university goals through the optimum utilization of resources and situation where academic programmes could not be run as scheduled resulting in adjustment of academic calendar, simply indicates ineffectiveness in terms of decline in the 
process of achieving the set goals. Jega (2003) observed that the Nigerian education sector in general has been experiencing a devastating crisis since the late 1970.According to Jega, in the Nigerian university system in particular this crisis has been characterized by a combination of chronic under funding, rapidly increasing students' enrolment, inadequacy of facilities, deterioration of physical infrastructures and suppression in managing the institutions, demoralization of staff and students, incessant student riots and periodic staff strike.

The governments and university administrators over the years were, however, not very successful in handling the conflicts, their authoritarian approaches worsens situation at times resulting in the incessant closures of the universities with the consequent disruption in academic calendar. In order to eradicate or reduce the conflict situation on university campuses, if the students are given proper place in university governance and duly recognized by the labour union on campus, issues affecting the labour unions that often lead to closure of the system could have been taken up by the students for speedy resolutions.

Despite the various importance attached to university education, it appears University education in Nigeria, is today faced with a lot of crises situations. The crises situations in Nigerian Universities today, have not been unconnected with the frequent students protest usually in the form of violent demonstration. This situation has led to perennial closure of the system as a result of which most of the academic calendars approved by Universities Senates are no longer followed strictly. It has been observed that the issue of having a unified academic calendar in Nigeria University has now become history. Students are only sure of date of admission, expected year of graduation is no longer known from inception. Parents/Guardians now incurred extra cost keeping their children/wards indefinitely in school. Also it has been observed that irregular academic calendar has also encouraged examination malpractices, cultism and other vices on Nigerian universities campuses.

However, the events of the past decades tended to suggest that the system of governance of the Nigerian Universities, both Federal and State needed a change for good students participation in institutional governance (Olayiwola1999). Adegun (2003) in one of his ten proposed principles towards keeping a University governance system healthy required that people who will be affected by a major decision have the right to be heard. Students may recent those decisions which they are not party to, and in an attempt by the University management to enforce such decisions may result into crisis situation thereby causing a disruption in academic calendar.

Based on the aforementioned problems, the study therefore investigated the level of students' participation in University governance and the level of organizational effectiveness in two tertiary institutions that are Federal and State owned in the study area.

\section{Purpose of the Study}

The purpose of this study was to investigate the level of students' participation in the governance of Universities. It also examined the level of organizational effectiveness of the universities. The difference in the students' participation in governance and organizational effectiveness were also investigated.

\section{Research Questions}

The following questions are raised to guide the study:

1. What is the level of students' participation in governance of Universities?

2. What is the level of organizational effectiveness of Universities?

\section{Research Hypotheses}

The following hypotheses are generated for the study:

1. There is no significant difference in students' participation in governance of Universities

2. There is no significant difference in the organizational effectiveness of Universities.

\section{Literature Review}

The involvement of students' participation in higher institutions governance is dated back to the early $19^{\text {th }}$ century, Olayiwola (1999). He further asserted that students activities, student self-government, student' participation or whatever name it is called, is as old as the schools of the ancient Greece.

The impact of the students' union government in instilling discipline among students' populace cannot be over 
emphasized. Ezekwen (2006) asserted that students' union governments are found in all universities in Nigeria and are generally very effective. By the students' union constitution the organization of the students' union government makes the student body easier to administer in that, it serves as the voice of the students. The management through the students' union government is able to know the feelings and request of the students. This view point was supported by longing (2000) that many institutions in Nigeria have established many committees to assist management in arriving at useful and meaningful decisions that can facilitate the proper management and growth of the university system of education.

In the same vein, Ajayi and Ayodele (2002) opined that students who have the large number of the university community should be well represented on all university committees for real democratization of the decision making process. In his own contribution Adesanoye (1989) opined that the rationale for students participation include among others, the development of ideas of right conduct, self-control, co-operative, fairness, provision of training in leadership. All these level of development would enable individual to be well acceptable in any organization.

An organization is an institution with some aims and objectives to achieve. One can say that an organization exists because something must be done, some objectives must be obtained. Bechr, and Newman (1998) asserted that organizational effectiveness is the concept of how effective an organization is in achieving the outcomes the organization intends to produce. This view was corroborated by Tajomavwo (2009) when he asserted that the effective organization is one that is able to achieve goals or results and is able to meet its obligations to all stakeholders now and in the distant future.

\section{Research Method}

This study employed a descriptive research design of the survey type. The population for this study consisted of all staff and students of universities in Ekiti and Ondo State of Nigeria. Purposive sampling technique was used to select Ekiti State University Ado-Ekiti and Federal University of Technology, Akure, Ondo State as sample for the study. Stratified random sampling techniques were used to select 400 students and 110 top university administrators from the two universities. The technique catered for the sub-groups interest within the population.

Two questionnaires were used to collect data. These are Students' Participation in University Governance Questionnaire (SPUGQ) which was administered to the students and Organizational effectiveness questionnaire (OEQ) which was given to key officers such as top administrators like the Registrars, Bursars, Libarians.Others include the Directors of Units, Deputy Registrars, Faculty officers and Principal administrative officers and head of department. The (OEQ) respondents were asked to indicate their agreement or disagreement on the items in the questionnaire. The questionnaire was validated by experts in Educational Management and Test and Measurement. The reliability of the instruments was ascertained using the test-retest method after which the scores were analyzed using the Pearson Product Moment Correlation. The reliability coefficient of 0.90 was obtained for (PSUG) and 0.84 was obtained for (OEQ). These results showed that the instrument was suitable for the study. The two hypotheses were tested at 0.05 level of significance.

\section{Results}

\subsection{Question 1: What is the level of students' participation in the governance of Universities?}

In analyzing this question, scores on students' participation in University governance were used. In order to determine the level of students' participation in university governance, the standard deviations were used to categorize the subject into three groups (Low, moderate and high).

Table 1: Level of Students' Participation in Governance of Universities.

\begin{tabular}{|l|c|c|c|c|c|c|}
\hline Students' Participation in & \multicolumn{2}{|c|}{ Federal University (FUTA) } & \multicolumn{2}{|c|}{ State University (EKSU) } & \multicolumn{2}{|c|}{} \\
\hline University Governance & Frequency & $\%$ & Frequency & $\%$ & Total & $\%$ \\
\hline Low 0-50.43 & 98 & 49.0 & 91 & 45.5 & 189 & 47.25 \\
\hline Moderate 50.44-62.00 & 53 & 26.5 & 60 & 30.0 & 113 & 28.25 \\
\hline High 62.01-100 & 49 & 24.5 & 49 & 24.5 & 98 & 24.5 \\
\hline Total & 200 & 100 & 200 & 100 & 400 & 100 \\
\hline
\end{tabular}

Table I shows the level of students participation in the university governance. The results shows that $189(47.25 \%)$ had 
low level of participation in the governance while $113(28.25 \%)$ had moderate level of participation. Those who had high level of participation were $98(24.5 \%)$. This shows that the level of students' participation in University governance was low.

\subsection{Question 2: What is the level of Organizational Effectiveness in Universities?}

Table 2: Level of Organizational effectiveness in Universities.

\begin{tabular}{|l|c|c|c|c|c|c|}
\hline Organization Effectiveness in Federal and State Universities & \multicolumn{2}{|c|}{ Federal University } & \multicolumn{2}{|c|}{ State University } & \multicolumn{3}{|c|}{} \\
\hline & Frequency & $\%$ & Frequency & $\%$ & Total & $\%$ \\
\hline Low (20-46.50) & 816 & 29.1 & 18 & 32.7 & 34 & 30.9 \\
\hline Moderate $(46.51-62.58)$ & 29 & 52.7 & 25 & 45.5 & 54 & 49.1 \\
\hline High $(62.59-100)$ & 1.0 & 18.2 & 21.8 & 22 & 20.0 & 24.5 \\
\hline
\end{tabular}

The result showed that out of 110 top universities administrators used for the study. 34 (30.9) adjudged the level of organization effectiveness as low. Those who had moderate level of organizational effectiveness were $54(49.1 \%)$ while $22(20.0 \%)$ had high level of organizational effectiveness. This implies that the level of organization effectiveness was moderate.

7.3 Hypothesis 1: There is no significant difference in students' participation in governance of Universities. This hypothesis was tested using responses from SPUGQ. The result was present in table 3

Table 3: t-test summary of students' participation in governance of Federal and State Universities.

\begin{tabular}{|c|c|c|c|c|c|c|}
\hline Items & $\mathrm{N}$ & $\mathrm{X}$ & SD & Df & t-cal & t-tab \\
\hline Federal University & 400 & 76.04 & 6.23 & & & \\
\hline State University & 400 & 68.77 & 5.96 & 148 & 3.52 & 1.960 \\
\hline
\end{tabular}

From the table 3 above, the calculated t-value 3.52 is greater than critical t-value 1.960 at 0.05 level of significance. Hence, the null hypothesis is rejected meaning that there was significant difference in the students' participation in governance of Federal and State Universities.

\subsection{Hypothesis 2: There is no significance difference in Organizational Effectiveness in Universities.}

Table : t-test summary of Organizational effectiveness in Universities.

\begin{tabular}{|c|c|c|c|c|c|c|}
\hline Items & $\mathrm{N}$ & $\mathrm{X}$ & SD & Df & t-cal & t-tab \\
\hline Federal University & 110 & 82.65 & 10.13 & & & \\
\hline State University & 110 & 70.88 & 8.04 & 98 & 2.136 & 1.960 \\
\hline
\end{tabular}

Table 4 showed that the t-calculated value was 2.316, while t-table value was 1.960. t-calculated value was greater than t-table value. The result was significant at 0.05 level, therefore the hypothesis was rejected. Hence, there was significant difference in the organizational effectiveness of Federal and State Universities.

\section{Discussion}

The study revealed that the level of students' participation in governance of Federal and State Universities in the study area was low. This low level of students' participation might not be unconnected with the fact that many University management failed to involve students' in the administration of their institutions adequately. The findings contradict Ajayi and Ayodele (2002) who asserted that the effective use of the committee system required the right person(s). Students who have the larger number of the university community should be well represented on all university committees for real democratization of the decision making process. The result also negates Ezekwem (2006) view that students' union 
participation in governance should be well encouraged and made generally very effective.

This study also revealed that the level of organizational effectiveness was moderate. The reason for this result might be due to the facts that the universities were able to achieve their set goals and objectives within the specified period of time. The findings agreed with Aluko (1997) Bechr and Newman (1998), Tajomarwo (2009) that organizational effectiveness is the one that is able to achieve goal or results and is able to meet its obligations to all stakeholders in which students are part. The study further revealed that there was significant difference in students' participation in governance of Federal and State Universities. Federal University has higher level of students' participation in University governance. This could be as a result of the Federal Universities using the same uniform standard for their students' involvement in the governance while each state university decides on their mode of governance. This finding was supported by Longing (2002) who stressed that many institutions in Nigeria have established many committees having students as members to assist management in arriving at useful and meaningful decisions that can facilitate proper management and the growth of University education.

The study revealed that there was significant difference in organizational effectiveness in federal and state Universities. The Organizational effectiveness of Federal University is higher than the State University. This can be attributed to the chronic under-funding, inadequacy of facilities, deterioration of physical infrastructure, lack of supervision, bad leadership leading to violent demonstration which also attracts perennial closure of the system that are more rampart among the state universities. The result was in line with Jega (2003) that the Nigerian education sector is generally has been experiencing a devastating crisis since the late 1970 in the areas of funding, provision of resources and leadership quality.

\section{Conclusion and Recommendations}

Based on the findings of the study, it was concluded that students had not been participating adequately in the governance of their institutions and that the organization effectiveness of both Federal and State universities were moderate The findings also revealed that students participation in governance and organizational effectiveness of Federal and State were higher than that of the State University.

In view of the significant difference in students' participation in governance and organizational effectiveness in Federal and State Universities, recommendations were made that the stake holders in university education should ensure that students in Federal and State Universities should ensure that students are more involved in the day to day running of their institutions. In order to enhance organizational effectiveness, the University management should organize courses; seminars and workshop on leadership training regularly for student leaders to assist them develop the skills needed to perform their challenging roles.

\section{References}

Adegun,O.A (2003)Sociology of Education" Ado-Ekiti Petoa Educational Publishers:

Adesanoye, A.P (1989). A study of students participation in school management; An unpublished M.Ed thesis O.A.U lle-lfe.

Ajayi, I.A. \& Ayodele J.B. (2002) Fundamentals of Educational Management, Greenline Publishers, Odo -ljigbo street, Ado-Ekiti

Aluko, M . Odegbesan, O.\& Gbadamosi L (1997); Business Policy and Strategy Rem of Themes Limited (Educational Publishers) Lagos. Nigeria.

Bechr, T \& Newman, J.E. (1998); Job stress, employee Health and Organizational effectiveness Retrived from, http://www.nga.org/files/pdf/0602creatinghealthy statework.pdf.

Ezekwem, E.C. (2006)(; students Unionism and University Administration in Nigeria Retrieved from http://publisher.com/proposals /568/index/html.

Jega, A (2003). The Role Union in University governance in Nigeria, A paper delivered at the national Association of Pro-Chancellors of Nigeria Universities Seminars held on 13 th to $14^{\text {th }}$ January, 2003.

Jonathan, O. (2008); Organizational change and stress management: A lecture delivered at a workshop on Effective language skills at U.I. Ibadan. $7^{\text {th }}-11^{\text {th }}$ April.

Longing T.C. (2002): Institutional governance: A call for collaborative decision making in America higher education. Baston, M.A maker publishing Co.

Olayiwola, O. (1999) Student Participation in Secondary School Administration in selected schools in Irewole Local Government Area, Oyo State" Unpublished M.Ed. Thesis, O.A.U. Ile-lfe

Patchem, M. (1970) Participation Achievement and Involvement on the Job Englewood Cliffs: Prentice Hall.

Tajomavno, G.A. (2009); Characteristics of effective organization; A Paper Delivered at a workshop on Enhancing Organization Change Lagos. 